Claremont Colleges

Scholarship@ Claremont

All HMC Faculty Publications and Research

HMC Faculty Scholarship

1-1-1979

\title{
A Survey of Ligand Effects Upon the Reaction Entropies of Some Transition Metal Redox Couples
}

Edmund L. Yee

Michigan State University

Robert J. Cave

Harvey Mudd College

Kendall L. Guyer

Michigan State University

Paul D. Tyma

Michigan State University

Michael J. Weaver

Michigan State University

\section{Recommended Citation}

Yee, E.L.; Cave, R. J.; Guyer, K.L.; Tyma, P.D.; Weaver, M.J. “A Survey of Ligand Effects Upon the Reaction Entropies of Some Transition Metal Redox Couples," J. Am. Chem. Soc., 1979, 101, 1131. DOI: 10.1021/ja00499a013

This Article is brought to you for free and open access by the HMC Faculty Scholarship at Scholarship @ Claremont. It has been accepted for inclusion in All HMC Faculty Publications and Research by an authorized administrator of Scholarship @ Claremont. For more information, please contact 


\title{
A Survey of Ligand Effects upon the Reaction Entropies of Some Transition Metal Redox Couples
}

\author{
Edmund L. Yee, Robert J. Cave, Kendall L. Guyer, Paul D. Tyma, and \\ Michael J. Weaver*
}

Contribution from the Department of Chemistry, Michigan State University, East Lansing, Michigan 48824. Received July 20, 1978

\begin{abstract}
The reaction entropies $\Delta S^{\circ}$ rc of a number of transition metal redox couples of the form M(III)/(II) in aqueous solution have been determined using nonisothermal electrochemical cells in order to explore the effect of varying the ligand structure upon the nature of the ion-solvent interactions. Examination of six aquo couples of the form $\mathrm{M}\left(\mathrm{OH}_{2}\right)_{n}{ }^{3+} / 2+$ with varying metal $\mathrm{M}$ yielded $\Delta S^{\circ} \mathrm{rc}$ values in the range $36-49 \mathrm{eu}$. In order to scrutinize the effect of replacing aquo with ammine and simple anionic ligands, Ru(III)/(II) couples were employed since the relative substitution inertness of both oxidation states allowed $\Delta S^{\circ}{ }_{\mathrm{rc}}$ to be determined using cyclic voltammetry. The stepwise replacement of aquo by ammine ligands results in substantial reductions in $\Delta S^{\circ}{ }_{\mathrm{rc}}$ which are attributed to the smaller extent of ligand-solvent hydrogen bonding for ammine compared with aquo ligands. Substitution of both aquo and ammine by anionic ligands also results in substantial reductions in $\Delta S^{\circ}{ }_{\mathrm{rc}}$. A num. ber of $\mathrm{M}(\mathrm{III}) /(\mathrm{II})$ couples containing chelating ligands were also examined. Sizable differences in $\Delta S^{\circ}$ re were found between $\mathrm{Co}(\mathrm{III}) /(\mathrm{II})$ couples and the corresponding $\mathrm{Ru}(\mathrm{III}) /(\mathrm{II})$ and $\mathrm{Fe}(\mathrm{III}) /(\mathrm{II})$ couples. Suggested explanations are differences in ligand conformation and electron delocalization effects. The possible contribution of outer-sphere solvent structuring effects to the large reorganization energies observed for electron exchange of aquo complexes is noted. The validity of the assumptions required for the estimation of $\Delta S^{\circ} \mathrm{rc}$ from nonisothermal cell measurements is discussed
\end{abstract}

\section{Introduction}

The entropies of transition-metal ions in aqueous solutions have long been known to be strongly dependent upon their charge and the nature of the coordinated ligands. ${ }^{1-3}$ These wide variations are undoubtedly due to differences in specific solvent structure surrounding the ions, such as "structure-making" and "structure-breaking" effects, ${ }^{4.5}$ as well as to classical electrostatic factors. ${ }^{6.7}$ Besides their intrinsic interest, a knowledge of partial molal ionic entropies, or at least the entropy difference $\Delta S^{\circ}{ }_{\mathrm{rc}}$ between the ions that form redox couples, also allows the entropic driving forces for redox reactions to be computed. The acquisition of such information should allow the achievement of a deeper understanding of the structural factors that influence the thermodynamics of redox processes than is possible from a knowledge of free energies alone.

Of particular interest in this connection is the effect upon $\Delta S^{\circ}{ }_{\mathrm{rc}}$ of varying the nature of the coordinated ligands for a given pair of oxidation states. Since $\Delta S_{\mathrm{rc}}^{\circ}$ is often large, this term can provide the dominant component of the free-energy driving force in electrode reactions. ${ }^{*}$ The entropy driving force for homogeneous redox reactions $\Delta S^{\circ}$ hum will tend to be smaller owing to a partial cancellation of $\Delta S^{\circ}{ }_{r c}$ for the two constituent redox couples, although $\Delta S^{\circ}{ }_{\mathrm{rc}}$ and consequently $\Delta S^{\circ}{ }_{\text {hom }}$ can be strongly dependent upon the nature of the coordinated ligands. However, the available data are relatively sparse and sometimes contradictory. The entropies of simple aquo cations are known to become markedly more negative with increasing positive charge 1.5 .6 so that $\Delta S^{\circ}{ }_{\mathrm{rc}}$ for a oneelectron redox couple is expected to be in the range $40-50 \mathrm{eu}$ (when written conventionally as a reduction). The substitution of coordinated water by large organic ligands has been found to result in much smaller values of $\Delta S^{\circ}{ }_{r c}$ which have been ascribed to the increased shielding of the metal cation from the surrounding water. ${ }^{9}$ However, few $\Delta S^{\circ}{ }_{\mathrm{rc}}$ data exist for other types of metal-complex couples. A major reason for this state of affairs is that most unidentate ligands do not form complexes in aqueous solution that are sufficiently stable with respect to dissociation, chemical oxidation, etc., in both oxidation states to allow $\Delta S^{\circ}{ }_{\mathrm{rc}}$ to be obtained directly from the temperature dependence of the equilibrium electrode potential. However, a number of ruthenium(III)/(II) couples have recently been shown to exhibit substitution inertness not only in the trivalent but also in the reduced state, at least on the time scale of electrochemical perturbation techniques such as cyclic voltammetry. ${ }^{10-14}$ Similar behavior is also exhibited by some osmium(III)/(II) ammine couples. ${ }^{\text {is }}$ Since these couples also exhibit complete electrochemical reversibility (i.e., rapid heterogeneous electron transfer) under these conditions, cyclic voltammetry can be used to obtain accurate values of the reversible cell potentials for these systems. ${ }^{10-15}$

We have used this technique to determine $\Delta S^{\circ}{ }_{\mathrm{rc}}$ for a series of $\mathrm{Ru}(\mathrm{III}) /(\mathrm{II})$ couples containing aquo, ammine, halide, and other simple unidentate ligands. These choices of systems were initially motivated by the desire to obtain values of $\Delta S^{\circ}{ }_{\mathrm{rc}}$ for mixed aquo and ammine complexes which might be used to estimate $\Delta S^{\circ}{ }_{r c}$ for the corresponding $\operatorname{Cr}($ III $) /($ II $)$ and $\mathrm{Co}(\mathrm{III}) /(\mathrm{II})$ reactions for comparison with the corresponding activation entropies for the heterogeneous reduction of these latter complexes. ${ }^{16}$ There is evidence from empirical entropy correlations ${ }^{1-3}$ to indicate that $\Delta S^{\circ}$ rc values for simple redox couples are primarily dependent on the nature of the coordinated ligands and on the charges on, rather than the nature of, the central metal ions. If this is the case, then $\Delta S^{\circ}{ }_{\mathrm{rc}}$ values for the large majority of redox systems for which such data are unobtainable could be inferred from the values for measurable systems with the same ligand constitution and charges. Such a rule is not unexpected, since the major contribution to $\Delta S^{\circ}{ }_{\mathrm{rc}}$ aside from dielectric polarization should arise from specific interactions such as hydrogen bonding between the ligands and the solvating water molecules. However, tests of this supposition are rare. We have therefore measured $\lambda S^{\circ}{ }^{\circ}$ for a number of $\mathrm{M}^{3+/ 2+}$ aquo couples for which the electronic structure of the central metal ion can be systematically varied.

In addition, we have determined $\Delta S^{\circ}$ rc for a number of more intricate $\mathrm{M}(\mathrm{III}) /(\mathrm{II})$ redox couples containing various chelating ligands. The high stability of these complexes allows the effect of varying the nature of the central metal ions to be further explored and enables the influence of specific solvation factors to be examined for couples containing large hydrophobic ligands which are of relevance to larger redox systems such as metalloproteins.

\section{Experimental Section}

Experimental Tactics. Nonisothermal Cells. It is desired to deter. mine the reaction entropy $\Delta S^{\circ}$ re for the redox couples 


$$
\mathrm{M}^{\mathrm{II}} \mathrm{L}_{\mathrm{m}}{ }^{\prime} \mathrm{L}_{n}{ }^{\prime \prime}+\mathrm{e}^{-} \text {(metal electrode) } \rightleftarrows \mathrm{M}^{\mathrm{I}} \mathrm{L}_{m}{ }^{\prime} \mathrm{L}_{n}{ }^{\prime \prime}
$$

in aqueous media, where $\mathrm{L}^{\prime}$ and $\mathrm{L}^{\prime \prime}$ are neutral or anionic ligands. Since reaction 1 is only one-half of a complete electrochemical cell reaction, its equlibrium properties cannot be determined without resort to extrathermodynamic assumptions. Indeed, the determination of individual ion free energies has been the subject of much debate over the years. ${ }^{17.18}$ Fortunately, however, there are a number of reliable routes to the quantitative estimation of individual ionic entropies, and especially $\perp S^{\circ}$ re. A useful summary of these methods has been given by Criss and Salomon. ${ }^{19}$ For the present purposes, the most convenient method involves the use of nonisothermal electrochemical cells. ${ }^{20.21}$ In this arrangement, the temperature of the half-cell containing the redox couple of interest is varied while the temperature of the other half-cell consisting of some convenient reference electrode is held constant. ${ }^{21}$ One such cell arrangement that was commonly used in the present work can be written as

$\mathrm{Cu}\left|\mathrm{Hg}_{\mathrm{g}}\right| \mathrm{Hg}_{2} \mathrm{Cl}_{2}(\mathrm{sat}), \mathrm{KCl}(\mathrm{sat})|| \mathrm{KCl}(3.5 \mathrm{M})|\mathrm{KCl}(3.5 \mathrm{M})|\left|\mathrm{M}^{\prime \prime \prime} . \mathrm{M}^{\prime \prime}\right| \mathrm{Hg}|\mathrm{Hg}| \mathrm{Cu}$

$$
T_{1}(\text { lixed }) \longrightarrow T_{2}(\text { varied }) \longrightarrow \longrightarrow T_{1} \longrightarrow
$$

The measured temperature coefficient $\mathrm{d} E_{\mathrm{f}}$ ni $/ \mathrm{d} T$ of the overall (formal) potential $E_{\mathrm{fi}}^{\mathrm{ni}}$ across such a nonisothermal cell which is reversible to the couple $\mathrm{M}^{111 / 11}$ can be separated into various components as in the equation

$$
\frac{\mathrm{d} E_{\mathrm{f}}^{\mathrm{ni}}}{\mathrm{d} T}=\frac{\mathrm{d} \phi_{1 \mathrm{lj}}}{\mathrm{d} T}+\frac{\mathrm{d} \phi_{\mathrm{tc}}}{\mathrm{d} T}+\frac{\mathrm{d} \phi_{\mathrm{f}}^{\mathrm{m}}}{\mathrm{d} T}
$$

$\phi_{\mathrm{ll} j}$ is the Galvani potential difference across the thermal liquid junction within the $\mathrm{KCl}$ salt bridge, $\phi_{\mathrm{tc}}$ is the "thermocouple" potential difference between the hot and cold regions of the mercury working electrode, $E_{f^{n i}}$ is the formal potential of the redox couple measured across the nonisothermal cell, and $\phi_{\mathrm{f}} \mathrm{m}$ is the corresponding Galvani metal-solution potential difference at the working electrode. Since

$$
F\left(\frac{\mathrm{d} \phi r^{m}}{\mathrm{~d} T}\right)=\Delta S^{\circ}{ }_{\mathrm{rc}}
$$

then if $\mathrm{d} \phi_{\mathrm{tc}} / \mathrm{d} T$ and $\mathrm{d} \phi_{\mathrm{tlj}} / \mathrm{d} T$ are known or can be estimated, $\Delta S_{\mathrm{rc}}^{\circ}$ can be obtained from measurements of $\mathrm{d} E_{\mathrm{f}}^{\mathrm{ni}} / \mathrm{d} T$. Absolute values of the Thomson coefficient $\mathrm{d} \phi_{\mathrm{tc}} / \mathrm{d} T$ are known for a number of metals; in most cases they amount only to a few microvolts per degree.$^{20}$ For mercury and platinum that we used in the present work over the temperature range $0-100^{\circ} \mathrm{C}, \mathrm{d} \phi_{\mathrm{tc}} / \mathrm{d} T$ is equal to about 14 and $6 \mu \mathrm{V}$ $\mathrm{deg}^{-1}$, respectively, ${ }^{22}$ These values are essentially negligible in comparison with the measured values of $\mathrm{d} E \mathrm{ri} / \mathrm{d} T$ and will be neglected. Although only relative rather than absolute values of $\mathrm{d} \phi_{\mathrm{tl}} / \mathrm{d} T$ are thermodynamically accessible, there is ample evidence that indicates that for most aqueous electrolytes, $\mathrm{d} \phi_{\mathrm{tl} j} / \mathrm{d} T \leqslant 50 \mu \mathrm{V} \mathrm{deg}-120.21$ For strongly acidic or alkaline media, markedly larger values of $\mathrm{d} \phi_{\mathrm{tl}} / \mathrm{d} T$ are obtained ${ }^{2} \mathrm{lb}$ which recall the large isothermal liquid junction potentials which can be generated in media containing $\mathrm{H}^{+}$or $\mathrm{OH}^{-}$ions. DeBethune et al. have suggested $21 \mathrm{~b}$ that $\mathrm{d} \phi_{\mathrm{tlj}} / \mathrm{d} T$ can be minimized by the use of concentrated aqueous potassium chloride in the region where the thermal gradient occurs (the so-called "nonisothermal salt bridge"). While the exact validity of this assumption has been questioned, $21 \mathrm{c}$ there is little doubt that $\mathrm{d} \phi_{1 \mathrm{lj}} / \mathrm{d} T$ for this arrangement is no greater than ca. $20 \mu \mathrm{V} \mathrm{deg}{ }^{-1}$, and probably much smaller. ${ }^{21} \mathrm{Al}$ though such uncertainties in $\mathrm{d} \phi_{\mathrm{llj}} / \mathrm{d} T$ are a serious concern for extremely accurate detcrminations of $\Delta S^{\circ}$, they are essentially negligible in the present experiments where a precision of only $\pm 50 \mu \mathrm{V}$ $\mathrm{deg}^{-1}$ could be reliably achieved for most systems. Since this uncertainty in $\mathrm{d} \phi_{1 \mathrm{li}} / \mathrm{d} T$ corresponds to an uncertainty in $\Delta S^{\circ} \mathrm{rc}$ of $\pm 1 \mathrm{eu}$, and variations in $\Delta S^{\circ}{ }_{\mathrm{rc}}$ of up to 50 eu were observed between the various redox systems reported here, such considerations are not of serious concern in the present study. (Also the relative values of $\Delta S^{\circ}{ }_{r c}$ for various systems will be unalfected by such considerations, as are the values of $\Delta S^{\circ}$ for homogeneous reactions that are obtained from the difference in $\Delta S^{\circ}$ ri for the appropriate pair of redox couples.) Such experiments therefore yield "absolute" entropy differences for redox couples which should be carefully distinguished from reaction entropies for completc electrochemical cells that are obtained from isothermal cell measurements, ${ }^{23}$ as well as those that have been computed by arbitrarily assigning the entropy of the hydrogen ion a value of zero. ${ }^{19.23}$

We chose to employ $3.5 \mathrm{M} \mathrm{KCl}$ in the nonisothermal salt bridge since the solubility of $\mathrm{KCl}$ is slightly greater than $3.5 \mathrm{M}$ even at the lowest temperature $\left(2^{\circ} \mathrm{C}\right)$ that was employed in our measurements. For experiments involving neutral supporting clectrolytes, the substitution of $3.5 \mathrm{M} \mathrm{KCl}$ instead of the electrolyte in the salt bridge resulted in small and usually negligible changes in $\mathrm{d} E_{\mathrm{f}}^{\mathrm{ni}} / \mathrm{d} T$, as expected. However, for supporting electrolytes where protons made a significant $(>5 \%)$ contribution to the total ionic strength, the substitution of these electrolytes by $3.5 \mathrm{M} \mathrm{KCl}$ in the salt bridge yiclded appreciable differences in $\mathrm{d} E_{\mathrm{f}} \mathrm{fi} / \mathrm{d} T$. Therefore, $3.5 \mathrm{M} \mathrm{KCl}$ was $\mathrm{cm}-$ ployed with these systems which served to minimize the isothermal liquid junction potentials between the salt bridge and the supporting electrolytes. For some experiments in concentrated perchlorate media, $3 \mathrm{M} \mathrm{NH}_{4} \mathrm{Cl}$ was used in the salt bridge in place of $\mathrm{KCl}$ to avoid the generation of spurious potentials from the precipitation of potassium perchlorate in the liquid junction. The electrochemical cell was constructed so that the temperature drop within the nonisothermal salt bridge occurred over a short distance $(<1 \mathrm{~cm})$ within glass tubing of internal diameter $\sim 0.8 \mathrm{~cm}$. These conditions ensured that there was only a negligible development of concentration polarization due to thermal diffusion (Soret effect), the presence of which could lead to larger values of $d \phi_{\mathrm{ujj}} / \mathrm{d} T{ }^{20,2 \mathrm{lb}}$ The absence of this effect, at least to a significant extent, was confirmed by the observed stability of the cell potentials within ca. $1 \mathrm{mV}$ for several hours under nonisothermal conditions.

The temperature dependence of the reversible potential $\left(\mathrm{d} E_{\mathrm{f}} \mathrm{ni} / \mathrm{d} T\right)$ could therefore be identified with the coefficient $\left(\mathrm{d} \phi_{1} \mathrm{~m} / \mathrm{d} T\right)$, which yields $\Delta S^{\circ}{ }_{\mathrm{rc}}$ from eq 3 . As mentioned above, $E_{\mathrm{f}}$ was determined for most systems using cyclic voltammetry rather than potentiometry because of the frequent instability of the reduced half of the redox couple. By working under the appropriate conditions, most of these couples could be made to exhibit reversible behavior. Then the electrode potential $E_{1 / 2}$ that is the average of the cathodic and anodic peak potentials is related to $E_{\mathrm{f}}$ by $E_{1 / 2}=E_{\mathrm{f}}+(R T / F) \ln \left(D_{11} / D_{\mathrm{III}}\right)^{1 / 2}$, where $D_{11}$ and $D_{11}$ are the diffusion coefficients of $M^{11}$ and $M^{11 !}$, respectively. ${ }^{24}$ Fortunately the ratio $D_{11} / D_{11}$ is usually close to unity so that $E_{1 / 2}$ is within $2-3 \mathrm{mV}$ of $E_{f}$. For the present purposes, it is only required that the temperature dependence of the term $(R T / F)$ ln $\left(D_{11} / D_{111}\right)^{1 / 2}$ be negligible so that $\mathrm{d} E_{1 / 2}{ }^{\mathrm{ni}} / \mathrm{d} T \approx \mathrm{d} E_{\mathrm{r}}$ ni $/ \mathrm{d} T$. This assumption was confirmed by determining $D_{11}$ and $D_{111}$ as a function of temperature for the representative systems $\mathrm{Eu}\left(\mathrm{OH}_{2}\right)_{n}{ }^{3+/ 2+}$ and $\mathrm{Ru}\left(\mathrm{NH}_{3}\right)_{6}{ }^{3+/ 2+}$ from the limiting polarographic and cyclic voltammetric peak currents for the appropriate reduced and oxidized species. Estimated errors of less than $0.5-1$ eu in $\Delta S^{\circ}$ re resulted by equating $\mathrm{d} E_{1 / 2}{ }^{n i} / \mathrm{d} T$ with $\mathrm{d} E_{\mathrm{f}}$ ni $/ \mathrm{d} T$.

Apparatus. Conventional two-compartment glass cells (solution volume ca. $10 \mathrm{~mL}$ ) were employed for the electrochemical measurements. The liquid junction between the working compartment and the salt bridge was formed using glass frits of "very fine" or "ultrafine" grade manufactured by Corning. Inc. (average porosity $1-3 \mu \mathrm{m}$ ), which prevented significant mixing of the two solutions on the time scale of each experiment $(2-3 \mathrm{~h})$. The working compartment, the liquid junction, and a portion of the salt bridge were surrounded by a common jacket through which was circulated water from a Braun Melsungen circulating thermostat. The temperature of the cell solutions could be controlled within $\pm 0.05^{\circ} \mathrm{C}$. The temperature of the reference electrode (saturated calomel electrode) that was immersed in the salt bridge solution was held at a fixed, ambient temperature along with the remaining portion of the salt bridge by means of a separate water jacket and circulator. For redox couples that exhibit formal potentials that are sufficiently negative to be examined at mercury electrodes, a commercial (Brinkmann Instruments) hanging mercury drop electrode (HMDE) was used. The other redox couples were examined using a platinum "flag" electrode consisting of a small (2-mm square) sheet of platinum spot-wclded to fine platinum wire. The design of both these electrodes ensured that rapid thermal equilibrium was achieved when the electrode was immersed in the solution. De polarograms were obtained using a capillary with a natural drop time of ca. $6 \mathrm{~s}$. Essentially complete thermal equilibrium at the growing drop was obtained under these conditions as evidenced by the identical kinetic parameters that were obtained over a range of temperatures at the dropping mercury electrode (DME) and the HMDE for the irreversible reductions of $\mathrm{Cr}^{3+}$ and $\mathrm{Eu}^{3+}$.

De pola rograms, as well as cyclic voltammograms with sweep rates in the region $50-1000 \mathrm{mV} \mathrm{s}^{-1}$ were obtained using a PAR 174 polarographic analyzer (Princeton Applied Research) coupled with a Hewlett-Packard Model $7045 \wedge$ fast $X-Y$ recorder. This arrangement 
Table I. Reaction Entropies $\triangle S^{\circ}{ }_{\mathrm{rc}}$ for Various $\mathrm{M}\left(\mathrm{OH}_{2}\right)_{n}{ }^{3+/ 2+}$ Redox Couples

\begin{tabular}{|c|c|c|c|c|}
\hline couple & electrolyte & $\begin{array}{c}E_{\mathrm{L} / 2^{25}, a} \\
\mathrm{mV} \mathrm{vs} . \\
\mathrm{SCE}\end{array}$ & $\begin{array}{l}\text { temp } \\
\text { range, } \\
{ }^{\circ} \mathrm{C}\end{array}$ & $\begin{array}{l}\Delta S^{\circ}{ }_{\mathrm{rc}}{ }^{d} \\
\text { cal } \mathrm{K}^{-1} \mathrm{~mol}^{-1} \text {, } \\
\text { at } 25^{\circ} \mathrm{C}\end{array}$ \\
\hline $\mathrm{Cr}\left(\mathrm{OH}_{2}\right)_{6} 3+/ 2+f$ & $1 \mathrm{M} \mathrm{NaClO}_{4}(\mathrm{pH} 2)$ & -660 & $3-60$ & $49^{b}$ \\
\hline $\mathrm{Fe}\left(\mathrm{OH}_{2}\right)_{6}^{3+/ 2+g}$ & $0.2 \mathrm{M} \mathrm{LiClO}_{4}(\mathrm{pH}-1.8)$ & 500 & $3-60$ & $43^{c}\left(48^{h}\right)$ \\
\hline $\mathrm{V}\left(\mathrm{OH}_{2}\right)_{6} 3+12+f$ & $0.2 \mathrm{M} \mathrm{LiClO}_{4}(\mathrm{pH}-1.8)$ & -475 & $3-60$ & $37^{c}$ \\
\hline \multirow{3}{*}{$\mathrm{Eu}\left(\mathrm{OH}_{2}\right)_{n}^{3+/ 2+f}$} & $0.02 \mathrm{M} \mathrm{NapTS}(\mathrm{pH} 3)^{e}$ & -628 & $3-60$ & $48.5^{\circ}$ \\
\hline & $0.1 \mathrm{M}$ NapTS $\left({\mathrm{pH} 3)^{e}}^{e}\right.$ & -626 & & $48^{\circ}$ \\
\hline & $1 \mathrm{M} \mathrm{NaClO}_{4}(\mathrm{pH} \mathrm{3})^{e}$ & -620 & & $45.5^{b, c}$ \\
\hline $\mathrm{Yb}\left(\mathrm{OH}_{2}\right)_{n} 3+12+f$ & $0.1 \mathrm{MKPF}_{6}(\mathrm{pH} \sim 5)^{e}$ & -1423 & $3-60$ & $48^{\circ}$ \\
\hline $\mathrm{Ru}\left(\mathrm{OH}_{2}\right)_{6}{ }^{3+/ 2+f}$ & $0.3 \mathrm{M} \mathrm{HpTS}^{j}$ & -16 & $3-50$ & $36^{c}\left(-33^{i}\right)$ \\
\hline
\end{tabular}

a Reversible "half-wave" potential determined in appropriate electrolyte, at $25^{\circ} \mathrm{C}$ against a SCE held at ambient temperature $(23 \pm 0.3$ $\left.{ }^{\circ} \mathrm{C}\right)$; related to formal potential $E_{\mathrm{f}}$ by $E_{1 / 2}{ }^{25}=E_{\mathrm{f}}{ }^{25}+(R T / F) \ln \left(D_{11} / D_{111}\right)^{1 / 2}$, where $D_{11}$ and $D_{111}$ are the diffusion coefficients of the reduced and oxidized species, respectively. For most systems $E_{\mathfrak{f}}=E_{1 / 2}-2( \pm 1) \mathrm{mV}$. ${ }^{b}$ Determined using combination of potentiometry and dc polarography. "Determined using cyclic voltammetry (sweep rates $50-500 \mathrm{mV} \mathrm{s}^{-1}$ ). ${ }^{d}$ Reaction entropy of redox couple (eq 1), defined as $\Delta S^{\circ} \mathrm{rc}$ $=S^{\circ}{ }_{11}-S^{\circ}{ }_{I I I}$, where $S^{\circ}{ }_{I I}$ and $S^{\circ}{ }_{I I I}$ are the "absolute" partial molal entropies of the reduced and oxidized species, respectively; determined from $J S^{\circ}{ }_{\mathrm{rc}}=F\left(\mathrm{~d} E_{1 / 2} \mathrm{ni} / \mathrm{d} T\right)$ for $T=25^{\circ} \mathrm{C}$. (For most systems $\Delta S^{\circ}{ }_{\mathrm{rc}}$ varied by less than \pm 2 eu over the temperature range studied.) Experimental precision estimated to be $\pm 1 \mathrm{eu}$, accuracy within $1-2$ eu (see text). Values in parentheses are from literature sources; see footnotes $h$ and $i \cdot{ }^{c} \mathrm{E}_{1 / 2}$ found to be unaffected by $\mathrm{pH}$ variations of at least one unit around $\mathrm{pH}$ value given. $f$ Determined using HMDE $\&$ Determined using Pt electrode. ${ }^{h}$ Calculated from ionic entropy data given in ref 1 by assuming that $S^{\circ} \mathrm{H}^{+}=-5$ eu. ${ }^{19} i$ Calculated from isothermal cell data given in ref 30 by noting that $\Delta S^{\circ}{ }_{\mathrm{rc}}$ for the reaction $\mathrm{H}^{+}+\mathrm{e}^{-} \rightleftharpoons 1 / 2 \mathrm{H}_{2}$ equals 21 eu. ${ }^{19,23 j} \mathrm{pTS}=p$-toluenesulfonate.

allowed peak potentials, etc., to be recorded with a precision of $\pm 1-2$ $\mathrm{mV}$. For faster voltammetric sweep rates $\left(1-100 \mathrm{Vs}^{-1}\right)$, a PAR 173 potentiostat driven by a digitally controlled sweep generator that was constructed in this department was employed along with a Tektronix Model $7623 \mathrm{~A}$ storage oscilloscope. These latter results were recorded using Polaroid film which resulted in a somewhat lower precision $( \pm 2-3 \mathrm{mV})$. All electrode potentials are quoted vs. a saturated calomel electrode (SCE) situated within the reference compartment which was thermostated close to ambient temperature $\left(23 \pm 0.3^{\circ} \mathrm{C}\right)$.

Materials and Syntheses. Most analytical grade reagents were used without further purification. Solutions for electrochemical experiments were prepared using water purified by double distillation from alkaline permanganate followed by "pyrodistillation", which consisted of repeatedly passing a mixture of steam and oxygen through a silica tube network held at $750^{\circ} \mathrm{C}$.

The ruthenium complexes employed in the present study were synthesized as follows. $\mathrm{Ru}\left(\mathrm{NH}_{3}\right)_{6} \cdot \mathrm{Cl}_{3}$ (Matthey Bishop. Inc.) was used as the starting material for the preparation of $\mathrm{Ru}\left(\mathrm{NH}_{3}\right)_{5} \mathrm{Cl} \cdot \mathrm{Cl}_{2}{ }^{25}$ $\mathrm{Ru}\left(\mathrm{NH}_{3}\right)_{5} \mathrm{Cl} \cdot \mathrm{Cl}_{2}$ in turn was used to prepare $\mathrm{Ru}\left(\mathrm{NH}_{3}\right)_{5} \mathrm{OH}_{2}{ }^{3+}, 10$ $\mathrm{Ru}\left(\mathrm{NH}_{3}\right)_{5} \mathrm{NCS} \cdot\left(\mathrm{ClO}_{4}\right)_{2},{ }^{10}$ and $\mathrm{Ru}\left(\mathrm{NH}_{3}\right)_{4} \mathrm{Cl}_{2} \cdot \mathrm{Cl}^{26} \mathrm{RuCl}_{3} \cdot 1-3 \mathrm{H}_{2} \mathrm{O}$ (Alfa Products) was used to prepare solutions of $\mathrm{Ru}\left(\mathrm{OH}_{2}\right)_{5} \mathrm{Cl}^{2+}$ and $\mathrm{Ru}\left(\mathrm{OH}_{2}\right)_{4} \mathrm{Cl}_{2}{ }^{+}$by refluxing in $0.1 \mathrm{M} p$-toluenesulfonic acid over mercury in a nitrogen atmosphere for several hours, followed by cation exchange separation using Dowex $50 \mathrm{~W}-\mathrm{X} 12$ resin. Solutions of $\mathrm{Ru}\left(\mathrm{OH}_{2}\right)_{6}{ }^{3+}$ were prepared by electrolyzing $\mathrm{Ru}\left(\mathrm{OH}_{2}\right)_{5} \mathrm{Cl}{ }^{2+}$ in 0.1 $\mathrm{M} p$-toluenesulfonic acid using a stirred mercury pool at $-300 \mathrm{mV}$ vs. SCE, adding a slight excess of $\mathrm{Ag}^{+}$to precipitate free chloride ions, filtering, and further electrolyzing at $+100 \mathrm{mV} v$ s. SCE to reoxidize $\mathrm{Ru}\left(\mathrm{OH}_{2}\right)_{6}{ }^{2+}$ to $\mathrm{Ru}\left(\mathrm{OH}_{2}\right)_{6}{ }^{3+}$ and to electrodeposit the excess $\mathrm{Ag}^{+}$. Samples of $\mathrm{Ru}(\mathrm{en})_{3} \cdot \mathrm{Br} r_{3}$, cis- $\mathrm{Ru}\left(\mathrm{NH}_{3}\right)_{4}\left(\mathrm{OH}_{2}\right)_{2} \cdot\left(\mathrm{CF}_{3} \mathrm{SO}_{3}\right)_{3}$, and $\mathrm{Ru}(\text { bpy })_{2} \mathrm{CO}_{3} \cdot 2 \mathrm{H}_{2} \mathrm{O}$ were kindly supplied by Dr. Gilbert Brown of Brookhaven National Laboratory. Solutions of cis-Ru(bpy $)_{2-}$ $\left(\mathrm{OH}_{2}\right)_{2}{ }^{2+}$ were generated by dissolving $\mathrm{Ru}(\text { bpy })_{2} \mathrm{CO}_{3} \cdot 2 \mathrm{H}_{2} \mathrm{O}$ in perchloric acid.

$\mathrm{Os}\left(\mathrm{NH}_{3}\right)_{6} \mathrm{l}_{3}$ was prepared from $\mathrm{Na}_{2} \mathrm{OsCl}_{6}{ }^{27}$ (Matthey Bishop, Inc.). Solutions of $\mathrm{Cr}^{3+}$ were prepared by reducing $\mathrm{CrO}_{3}$ with $\mathrm{H}_{2} \mathrm{O}_{2}$ in excess perchloric acid. Solutions of $\mathrm{V}^{3+}$ were prepared by dissolving $\mathrm{V}_{2} \mathrm{O}_{5}$ in excess perchloric acid. electroreducing to $\mathrm{V}^{2+}$ at a stirred mercury pool held at $-1100 \mathrm{mV}$ vs. SCE, and reoxidizing to $\mathrm{V}^{3+}$ at $-300 \mathrm{mV}$ vs. SCE. Solutions of $\mathrm{Eu}^{3+}$ and $\mathrm{Yb}^{3+}$ were prepared by dissolving $\mathrm{Eu}_{2} \mathrm{O}_{3}$ and $\mathrm{Yb}_{2} \mathrm{O}_{3}$ in a slight excess of perchloric acid. $\mathrm{Co}(\mathrm{en})_{3} \cdot \mathrm{Cl}_{3}$ was prepared as in ref 28 . Solutions of $\mathrm{Fe}(\mathrm{bpy})_{3}{ }^{2+}, \mathrm{Fe}-$ (phen $)_{3}{ }^{2+}, \mathrm{Co}(\mathrm{bpy})_{3}{ }^{2+}$, and $\mathrm{Co}(\text { phen })_{3}{ }^{2+}$ were prepared by adding an excess of the appropriate ligand to a solution of the given metal ion. The various Co(III) macrocycle complexes scrutinized here were kindly provided by Professor John Endicott of Wayne State University.

\section{Results}

1. Aquo Couples. The reaction entropy $\Delta S^{\circ}{ }_{\mathrm{rc}}$ of six aquo couples of the type $\mathrm{M}\left(\mathrm{OH}_{2}\right)_{n}{ }^{3+/ 2+}$ were studied: $\mathrm{Cr}$ $\left(\mathrm{OH}_{2}\right)_{6}^{3+/ 2+}, \quad \mathrm{V}\left(\mathrm{OH}_{2}\right)_{6}^{3+/ 2+}, \quad \mathrm{Fe}\left(\mathrm{OH}_{2}\right)_{6}{ }^{3+/ 2+}, \quad \mathrm{Ru}-$ $\left(\mathrm{OH}_{2}\right)_{6}{ }^{3+/ 2+}, \mathrm{Eu}\left(\mathrm{OH}_{2}\right)_{n}{ }^{3+/ 2+}$, and $\mathrm{Yb}\left(\mathrm{OH}_{2}\right)_{n}{ }^{3+/ 2+}$. These systems were chosen because their formal potentials allow them to be conveniently studied at mercury or platinum electrodes, and they exhibit substantial variations in electronic structure of the central metal ions. Previous determinations of $\Delta S^{\circ}{ }_{r c}$ for these couples are sparse. The absolute ionic entropies of $\mathrm{Fe}^{3+}$ and $\mathrm{Fe}^{2+}$ have been determined, ${ }^{29}$ and an estimate of $\Delta S^{\circ} \mathrm{rc}$ for $\mathrm{Ru}\left(\mathrm{OH}_{2}\right)_{6}{ }^{3+/ 2+}$ has been reported from electrochemical measurements. ${ }^{30}$

Most data for the $\mathrm{Cr}^{3+/ 2+}$ and $\mathrm{Eu}^{3+/ 2+}$ couples in perchlorate media were obtained using potentiometry because the small heterogeneous electron transfer rates for these systems resulted in distinctly irreversible cyclic voltammograms. However, by working in sodium $p$-toluenesulfonate (NapTS) media, the strong specific adsorption of $p$-toluenesulfonate anions resulted in almost reversible cyclic voltammograms for the $\mathrm{Eu}^{3+/ 2+}$ couple. Accurate values of $E_{1 / 2}$ could still be obtained from such "quasi-reversible" voltammograms in the usual way provided that the cathodic-anodic peak separation lies in the range 57 to $\mathrm{ca} .90 \mathrm{mV} .{ }^{24 b}$ For the remaining aquo couples, essentially reversible or quasi-reversible cyclic voltammograms were obtained, at least after the addition of small quantities of NapTS. The resulting values of $\Delta S^{\circ}{ }_{\mathrm{rc}}$ are listed in Table I, together with other pertinent information. It is seen that some limited dependence of $\Delta S^{\circ}{ }_{\mathrm{rc}}$ upon the nature of the metal ion is obtained. The dependence of $\Delta S^{\circ}$ rc upon ionic strength was investigated for $\mathrm{Eu}^{3+/ 2+}$ and was found to be small (Table I). Good agreement between the earlier and present determinations is found for $\mathrm{Fe}\left(\mathrm{OH}_{2}\right)_{6}{ }^{3+/ 2+}$ (Table I), but a large qualitative discrepancy is seen for Ru$\left(\mathrm{OH}_{2}\right)_{6}{ }^{3+/ 2+}$. A possible reason for this discrepancy is that the isothermal cell measurements of ref 30 were complicated by an unknown temperature dependence of the electrode potential of the glass reference electrode used in that study.

2. Ruthenium(III)/(II) and Osmium(III)/(II) Couples. The reaction entropies of $12 \mathrm{Ru}(\mathrm{III}) /(\mathrm{II})$ couples containing ammine, aquo, and simple anionic ligands were evaluated. These systems were selected in order to scrutinize the effects 
Table II. Reaction Entropies $\Delta S^{\circ}{ }_{\mathrm{rc}}$ for Various $\mathrm{Ru} \mathrm{u}^{11 / / 1}$ and $\mathrm{Os}{ }^{111 / 1 /}$ Redox Couples

\begin{tabular}{|c|c|c|c|c|}
\hline couple & electrolyte & $\begin{array}{l}-E_{1 / 2} 25, a \\
m V \text { vs. SCE }\end{array}$ & $\begin{array}{l}\text { temp } \\
\text { range, } \\
{ }^{\circ} \mathrm{C}\end{array}$ & $\begin{array}{c}\Delta S^{\circ} \mathrm{rc}^{b} \\
\text { cal } \mathrm{K}^{-1} \mathrm{~mol}^{-1} \text {, } \\
\text { at } 25^{\circ} \mathrm{C}\end{array}$ \\
\hline \multirow{5}{*}{$\mathrm{Ru}\left(\mathrm{NH}_{3}\right)_{6}{ }^{3+/ 2+}$} & $0.02 \mathrm{M} \mathrm{KPF}_{6}$ & 175 & $3-60$ & $19 \pm 0.5^{c}$ \\
\hline & $0.25 \mathrm{M} \mathrm{KPF}_{6}$ & $183\left(193^{10}, 187^{12}\right)$ & $15-60$ & $17 \pm 0.5^{c}$ \\
\hline & $0.1 \mathrm{M} \mathrm{NaClO}_{4}$ & 178 & $15-60$ & $19 \pm 0.5^{c, d}\left(7^{31}\right)$ \\
\hline & $0.2 \mathrm{MCF}_{3} \mathrm{COONa}$ & 180 & $3-60$ & $16.5 \pm 0.5^{c}$ \\
\hline & $0.8 \mathrm{M} \mathrm{CF}_{3} \mathrm{COONa}$ & 188 & $3-60$ & $14 \pm 0.5$ \\
\hline $\mathrm{Os}\left(\mathrm{NH}_{3}\right)_{6^{3+}}+2+$ & $0.05 \mathrm{MCF}_{3} \mathrm{COONa}$ & $990\left(1010^{14}\right)$ & $3-65$ & $18 \pm 0.5^{\circ}$ \\
\hline $\operatorname{Ru}(\mathrm{en})_{3}^{3+/ 2+}$ & $0.1 \mathrm{M} \mathrm{KPF}_{6}$ & 60 & $3-60$ & $13 \pm 0.5^{6}\left(11^{31}\right)$ \\
\hline $\mathrm{Ru}\left(\mathrm{NH}_{3}\right)_{5} \mathrm{OH}_{2}{ }^{3+/ 2+}$ & $0.2 \mathrm{M} \mathrm{CF}_{3} \mathrm{COOH}$ & $162\left(178 . .^{10} 174^{12}\right)$ & $3-60$ & $25 \pm 2^{c}\left(17.5^{31}\right)$ \\
\hline cis $-\mathrm{Ru}\left(\mathrm{NH}_{3}\right)_{4}\left(\mathrm{OH}_{2}\right)_{2}{ }^{3+/ 2+}$ & $0.1 \mathrm{M} \mathrm{HpTS}^{e}$ & $135\left(144,,^{10} 140^{12}\right)$ & $3-60$ & $26 \pm 2^{c}$ \\
\hline $\mathrm{Ru}\left(\mathrm{NH}_{3}\right)_{5} \mathrm{OH}^{2+1+}$ & $0.2 \mathrm{M} \mathrm{NaOH}$ & $653\left(664^{10}\right)$ & $5-50$ & $0 \pm 3^{c}$ \\
\hline \multirow[t]{2}{*}{$\mathrm{Ru}\left(\mathrm{NH}_{3}\right)_{5} \mathrm{NCS}^{2+/+}$} & $0.02 \mathrm{M} \mathrm{KPF}_{6}$ & 130 & $3-60$ & $15 \pm 0.5$ \\
\hline & $0.4 \mathrm{M} \mathrm{KPF}_{6}$ & $140\left(111^{10}\right)$ & $3-60$ & $15 \pm 0.5^{c}$ \\
\hline $\mathrm{Ru}\left(\mathrm{NH}_{3}\right)_{5} \mathrm{Cl} 2+1+$ & $0.5 \mathrm{M} \mathrm{NaClO}_{4}$ & $295\left(286^{10}\right)$ & $2-45$ & $10 \pm 2^{d}$ \\
\hline cis. $\mathrm{Ru}\left(\mathrm{NH}_{3}\right)_{4} \mathrm{Cl}_{2}+10$ & $1 \mathrm{M} \mathrm{VaClO}_{4}$ & $350\left(344,^{10} 326^{12}\right)$ & $2-28$ & $10 \pm 4^{d}$ \\
\hline $\mathrm{Ru}\left(\mathrm{OH}_{2}\right)_{6}{ }^{3+/ 2+}$ & $0.3 \mathrm{M} \mathrm{HpTS}^{e}$ & $16\left(30^{30}\right)$ & $3-50$ & $38 \pm 3^{c}\left(-33^{30}\right)$ \\
\hline $\mathrm{Ru}\left(\mathrm{OH}_{2}\right)_{5} \mathrm{Cl}^{2+/+}$ & 1 M HpTS & 165 & $3-40$ & $28 \pm 3^{i}$ \\
\hline cis- $\mathrm{Ru}\left(\mathrm{OH}_{2}\right)_{4} \mathrm{Cl}_{2}+/ 0$ & $0.1 \mathrm{M} \mathrm{HpTS}^{e}$ & 268 & $4-35$ & $25 \pm 2$ \\
\hline
\end{tabular}

"Reversible "half-wave" potential determined by cyclic voltammetry at a HMDE (see notes for Table 1). Values in parentheses are from indicated literature sources and correspond to comparable experimental conditions, ${ }^{b}$ Reaction entropy of redox couple (see notes for Table 1). Stated precision was estimated from scatter of experimental points in the vicinity of $25^{\circ} \mathrm{C}$. Values in parentheses are from indicated literature sources. " Determined using cyclic voltammetric sweep rates in the range $50-500 \mathrm{mV} \mathrm{s}^{-1}$. "Determined using swcep rates in the range $1-100$ $V s^{-1}, " p T S=p$-toluenesulfonate.

Table III. Reaction Entropies $\Delta S^{\circ}{ }_{r c}$ for Various $\mathrm{M}^{111 / 11}$ Couples Containing Chelating Ligands

\begin{tabular}{|c|c|c|c|c|}
\hline couple & electrolyte & $\begin{array}{c}E_{1 / 2}{ }^{25}, a \\
\mathrm{~m} V \text { vs. SCE }\end{array}$ & $\begin{array}{c}\text { temp } \\
\text { range, } \\
{ }^{\circ} \mathrm{C}\end{array}$ & $\begin{array}{l}\Delta S^{\circ} \mathrm{rc}^{b} \\
\text { cal } \mathrm{K}^{-1} \mathrm{~mol}^{-1} \text {, } \\
\text { at } 25^{\circ} \mathrm{C}\end{array}$ \\
\hline $\begin{array}{l}\operatorname{Ru}(\text { en }) 3^{3+/ 2+} \\
\operatorname{Co}\left(\text { en } 3_{3}^{3+12+i}\right. \\
\operatorname{Fe}\left(\text { phen } 3_{3}^{3+/ 2+d}\right.\end{array}$ & $\begin{array}{l}0.1 \mathrm{M} \mathrm{KPF}_{6} \\
1 \mathrm{M} \mathrm{NaClO} \\
\\
0.05 \mathrm{M} \mathrm{KCl} \\
+25 \mathrm{mM} \text { phen }\end{array}$ & $\begin{array}{l}-60 \\
-460\left(-448, \mu=0^{32}\right) \\
870\left(865, \mu=0.05^{33}\right)\end{array}$ & $\begin{array}{l}3-60 \\
3-60 \\
4-45\end{array}$ & $\begin{array}{l}13 \pm 0.5\left(11^{31}\right) \\
37 \pm 2\left(40,,^{32} \mu=0\right) \\
3 \pm 2(0, \mu=09.33)\end{array}$ \\
\hline $\mathrm{Fe}(\text { bpy })_{3} 3+/ 2+d$ & $\begin{array}{l}0.05 \mathrm{M} \mathrm{KCl} \\
+25 \mathrm{~m} \mathrm{M} \mathrm{bpy}\end{array}$ & $845\left(845, \mu=0.05^{33}\right)$ & $4-45$ & $2 \pm 2\left(2, \mu=0^{9.33}\right)$ \\
\hline cis- Ru(bpy) $)_{2}\left(\mathrm{OH}_{3}\right)_{2}{ }^{3+/ 2+a}$ & $0.1 \mathrm{M} \mathrm{HpTS}$ & 652 & $3-60$ & $2 \pm 2$ \\
\hline $\mathrm{Co}(\text { phen })^{3+/ 2+d}$ & $\begin{array}{l}0.05 \mathrm{M} \mathrm{KCl} \\
+25 \mathrm{mM} \text { phen }\end{array}$ & 145 & $3-45$ & $22 \pm 3\left(18^{g}\right)$ \\
\hline $\operatorname{Co}($ bpy $) 3^{3+/ 2+d}$ & $\begin{array}{l}0.05 \mathrm{M} \mathrm{KCl} \\
+25 \mathrm{mM} \mathrm{bpy}\end{array}$ & 70 & $3-40$ & $22 \pm 3(2 \mid g)$ \\
\hline Co(sepulchrate $)^{3+/ 2+f}$ & $0.1 \mathrm{M} \mathrm{NaClO}$ & $-540\left(-540^{34}\right)$ & $3-50$ & $19 \pm 2$ \\
\hline $\mathrm{Co}(1-[14]$ diene $)\left(\mathrm{OH}_{2}\right)_{2}^{3+/ 2+d e}$ & $0.1 \mathrm{M} \mathrm{HClO}_{4}$ & $315\left(315^{35 b}\right)$ & $3-55$ & $45 \pm 2$ \\
\hline $\mathrm{Co}(\mathrm{TIM})\left(\mathrm{OH}_{2}\right)_{2}^{3+/ 2+d e}$ & $0.1 \mathrm{M} \mathrm{HClO}_{4}$ & $315\left(300^{35 b}\right)$ & $3-55$ & $23 \pm 5$ \\
\hline
\end{tabular}

"Reversible "half-wave" potential determined by cyclic voltammetry using sweep rates of $50-500 \mathrm{mV} \mathrm{s}-1$ (see notes for Table I). Values in parentheses are taken from indicated literature souress. $\mu$ is ionic strength. ${ }^{h}$ Realetion entropy of redox couple (for details see notes for Tables I ind II). "Determined using HMDE. "Determined using Pt electrode. "Nomenclature as in ref 35. $t-[14]$ diene $=5,7.7,12,14,14-h e x i l-$ methyl-1,4,8,11-tetraazacyclotetradeca-4,11-diene; TIM = 2,3,9,10-tetramethyl-1,4,8,11-tetraazacyclotetradeca-1,3,8,10-tetraene. / Nomenclature as in ref $34 . g$ Calculated from isothermal cell data [A. Ciana and V. Crescenzi, quoted by M. Chou, C. Creutz, and V. Sutin, J. Am. (hem. Soc., 99, 5616 (1977), Table V] by assuming that $\Delta S^{\circ}{ }_{\mathrm{rc}}$ for $\mathrm{H}^{+}+\mathrm{c}^{-} \rightleftharpoons 1 / 2 \mathrm{H}_{2}$ equals 21 cu. ${ }^{19.23}$

of replacing ammine by aquo ligands and of changing the charge type of the couple resulting from substitution of the ammine and aquo ligands by simple anions. The results are summarized in Table II. For all these systems, the heterogeneous electron transfer rates were sufficiently rapid so that the cyclic voltammograms were essentially reversible even at the highest sweep rates $\left(100 \mathrm{~V} \mathrm{~s}^{-1}\right)$. However, the relative lability of the $\mathrm{Ru}$ II state for the $\mathrm{Ru}\left(\mathrm{NH}_{3}\right)_{5} \mathrm{Cl}^{2+/+}$ and $\mathrm{Ru}\left(\mathrm{NH}_{3}\right)_{4}-$ $\mathrm{Cl}_{2}{ }^{+/ 0}$ couples necessitated the use of large sweep rates $(1-100$ $\left.\mathrm{V}^{-1}\right)$ in order to avoid significant aquation of Rull during the potential scan. Estimates of $\Delta S^{\circ}$ rc have previously been obtained for $\mathrm{Ru}\left(\mathrm{NH}_{3}\right)_{6}{ }^{3+/ 2+}, \mathrm{Ru}\left(\mathrm{NH}_{3}\right)_{5} \mathrm{OH}_{2}{ }^{3+/ 2+}$, and $\mathrm{Ru}(\mathrm{en})_{3} 3^{3+2+}$ from the temperature dependence of the equilibrium constants for reduction of the Ru(III) complexes by
$\mathrm{Np}^{3+}$ coupled with an estimate of $\Delta S^{\circ}{ }_{\mathrm{r}}$ for the $\mathrm{Np}^{4+/ 3+}$ couple. ${ }^{31}$ While reasonable agreement between the present and earlier determinations is found for $\mathrm{Ru}(\mathrm{en}) 3^{3+/ 2+}$, substantial differences are seen for the other two systems (Table II). These discrepancies may arise from systematic errors in the kinetic analysis employed to determine the equilibrium constants in ref 31 when these quantities are much larger than unity. Significant differences are also seen between present and earlier determinations of $E_{1 / 2}$ for some $\mathrm{Ru}$ (III)/(II) couples (Table II). In view of the care taken to minimize liquid junction potentials in the present work, these differences probably arise chiefly from the presence of such potentials in the earlicr work combined with the slightly different thermal conditions employed here. 
Two main trends are seen upon inspecting the data given in Table II. Firstly, the stepwise replacement of ammonia by aquo ligands results in large increases in $\Delta S^{\circ}{ }_{\mathrm{rc}}$. Secondly, the substitution by anionic ligands results in significant decreases in $\Delta S^{\circ}{ }_{\mathrm{rc}}$. A value of $\Delta S^{\circ}{ }_{\mathrm{rc}}$ for $\mathrm{Os}\left(\mathrm{NH}_{3}\right)_{6}{ }^{3+/ 2+}$ is also given in Table II for comparison with $\mathrm{Ru}\left(\mathrm{NH}_{3}\right)_{6}{ }^{3+/ 2+}$. The reaction entropies for these two systems containing the same ligands are in close agreement.

3. Redox Couples Containing Chelating Ligands. In contrast to redox couples containing only simple unidentate ligands as considered above, a significant quantity of information has been gathered previously on the reaction entropies of couples containing chelating ligands. One reason is that such complexes are often sufficiently stable so that even labile oxidation states can remain in the complexed form in the presence of small stoichiometric excesses of the chelating ligands. Consequently it becomes feasible to determine values of $\Delta S^{\circ}{ }_{\mathrm{rc}}$ for redox pairs such as $\mathrm{Co}(\mathrm{III}) /(\mathrm{II})$ when bound to some chelating ligands. The lability coupled with the weak complexing ability of the $\mathrm{Co}$ (II) state precludes such studies of $\mathrm{Co}$ (III)/(II) couples containing only unidentate ligands. The simplest example is $\mathrm{Co}(\mathrm{en}) 3^{3+/ 2+}$, which provides an interesting comparison with $\mathrm{Ru}(\mathrm{en})_{3}{ }^{3+12+}$. The relevant data for these couples are given in Table 1II. It is seen that the values of $\Delta S^{\circ}$ rc for these two redox couples are strikingly different. The large value of $\Delta S^{\circ} \mathrm{rc}$ for $\mathrm{Co}(\mathrm{en}) 3^{3+/ 2+}(37 \mathrm{eu})$ is surprising in view of the markedly smaller values seen for other amine complexes (Table II) but is in accord with an earlier determination. ${ }^{32}$

Consequently, we decided to evaluate $\Delta S^{\circ}$ rc for some other related $\mathrm{Co}$ (III)/(II) couples. The tris-1,10-phenanthroline and tris-2,2-bipyridine $\mathrm{Fe}(\mathrm{III}) /(\mathrm{II})$ and $\mathrm{Ru}$ (III)/(II) couples have previously been found to exhibit values of $\Delta S^{\circ}{ }_{\mathrm{rC}}$ that are close to zero. 9.33 The present determinations of $\Delta S^{\circ}{ }_{\mathrm{rc}}$ for $\mathrm{Fe}$ (phen) $3^{3+/ 2+}$ and $\mathrm{Fe}(\text { bpy })_{3}{ }^{3+/ 2+}$ are in close agreement with these earlier values. A small value of $\Delta S^{\circ}{ }_{r c}$ is maintained even for cis-Ru(bpy $)_{2}\left(\mathrm{OH}_{2}\right)_{2}{ }^{3+/ 2+}$ (Table III). However, the measured values of $\Delta S^{\circ}$ ic for $\mathrm{Co}$ (phen $3^{3+/ 2+}$ and $\mathrm{Co}-$ (bpy) $3^{3+/ 2+}$ are both substantially different from zero (ca. +25 eu, Table III). It therefore again appears that such Co(III)/ (II) amine couples exhibit "anomalously" large $\Delta S^{\circ}{ }_{\text {IC }}$ values. On the other hand, $\Delta S^{\circ}$ rc for the "capped ethylenediamine" Co(sepulchrate) ${ }^{3+12+}$ couple 34 is much smaller than for $\mathrm{Co}(\mathrm{en}) 3^{3+12+}$ (Table III). In this connection, it is also of interest to examine $\Delta S^{\circ}$ for planar macrocyclic $\mathrm{Co}(\mathrm{III}) /(\mathrm{II})$ couples. In Table II are listed results for two typical systems, $\mathrm{Co}(t-[14]$ diene $)\left(\mathrm{OH}_{2}\right)_{2}{ }^{3+1 / 2+}$ and $\mathrm{Co}(\mathrm{TIM})\left(\mathrm{OH}_{2}\right)_{2}{ }^{3+2+2+35}$ Some difficulty was experienced in obtaining accurately reproducible results for the latter system. Nevertheless the values of $\Delta S^{\circ}$ for both these couples are again substantial, yet markedly different.

\section{Discussion}

It has been known for some time that the entropies of simple aquo cations can be correlated with surprising success using empirical relations involving the ionic charges and radii. ${ }^{1,6}$ Using the I.atimer Powell relation' and known crystallographic radii, ${ }^{36} \Delta S^{\circ}$ for the first-row transition-metal couples in Table I are calculated to be ca. $45 \mathrm{eu}$, in good agreement with the experimental results. However, the smaller observed value for $\mathrm{Ru}\left(\mathrm{OH}_{2}\right)_{6}{ }^{3+12+}(36 \mathrm{eu})$ and the larger values for $\mathrm{Eu}\left(\mathrm{OH}_{2}\right)_{n}{ }^{3+1 / 2+}$ and $\mathrm{Yb}\left(\mathrm{OH}_{2}\right)_{n}{ }^{3+/ 2+}(48 \mathrm{eu})$ are not predicted by this relation. The classical Born equation can only yield predicted values of $\lrcorner S^{\circ} \mathrm{rc}$ in reasonable agreement with these results by inserting the radii of the bare cations, ${ }^{6}$ rather than the radii including the coordinated water molecules which seem intuitively more reasonable choices, especially for transitionmetal cations. These large experimental values of $\Delta S^{\circ}{ }_{\mathrm{rc}}$ are probably a consequence of the release of water molecules surrounding the primary coordination sphere that are strongly orientated ("frozen") in the tripositive oxidation state. ${ }^{4}$ Indeed, such solvent structuring effects provide the most widely accepted and intuitively reasonable umbrella for rationalizing the observed wide variations in $\Delta S^{\circ}{ }_{\mathrm{rc}}{ }^{4,5,9}$

In this connection, it is interesting to note that simple $\mathrm{M}(\mathrm{III}) /(\mathrm{II})$ ammine couples exhibit values of $\Delta S^{\circ}{ }_{\mathrm{rc}}$ which are substantially less than for the corresponding aquo couples (Tables I and II). Thus, for both $\mathrm{Ru}\left(\mathrm{NH}_{3}\right)_{6}{ }^{3+} / 2+$ and $\mathrm{Os}\left(\mathrm{NH}_{3}\right)_{6}{ }^{3+/ 2+}, \Delta S^{\circ}{ }_{\mathrm{re}} \approx 18 \mathrm{eu}$, whereas for $\mathrm{Ru}\left(\mathrm{OH}_{2}\right)_{6}{ }^{3+/ 2+}$ and other hexaaquo couples, $\Delta S^{\circ}{ }_{\mathrm{rc}}>35 \mathrm{eu}$. Since the size, shape, and electrostatic properties of ammonia and water ligands are comparable, ${ }^{37}$ these differences suggest that rather specific interactions between the coordinated and surrounding water molecules are responsible for the large values of $\Delta S^{\circ}{ }_{r c}$ observed for the latter systems. It seems reasonable that the large degree of solvent ordering around tripositive, compared to dipositive, aquo cations arises partly from the ability of the relatively acidic aquo protons to form hydrogen bonds with surrounding water molecules. ${ }^{4}$ The weakly acidic ammine protons presumably have a much lower tendency to aid the central cationic charge in orienting solvating water molecules in this manner. These results are not unexpected on the basis of the empirical entropy correlation of George et al., which also indicates that the entropies of ammine complexes decrease less with increasing cationic charge compared with aquo systems. ${ }^{3}$ The much lower "structure-making" ability of tripositive ammine, compared with aquo, complexes is also borne out by the much smaller effective hydrated radii for ion transport that are observed for the former complexes. ${ }^{38}$ The differing magnitudes in the electrostatic double layer effects observed for the electroreduction of $\mathrm{Cr}$ (III) aquo and ammine complexes suggests that such differences in the extent of hydration also survive within the electrode-solution interfacial region. ${ }^{39}$ Since the Born relation predicts for $3+/ 2+$ couples that $\Delta S^{\circ}{ }_{\mathrm{TC}}=$ $47.1 / r_{\mathrm{c}} \mathrm{eu}$, where $r_{\mathrm{c}}$ is the effective radius of the ion, 6.7 and the radius of $\mathrm{M}\left(\mathrm{NH}_{3}\right)_{6}{ }^{3+/ 2+}$ is ca. $3 \AA,{ }^{37}$ then this relation predicts for the couples $\Delta S^{\circ}{ }_{\mathrm{rc}} \approx 16 \mathrm{eu}$. The close agreement between the Born prediction and the experimental results for $\mathrm{Ru}\left(\mathrm{NH}_{3}\right)_{6}{ }^{3+/ 2+}$ and $\mathrm{Os}\left(\mathrm{NH}_{3}\right)_{6}{ }^{3+/ 2+}$ (Table II) suggests that there is no extensive solvent ordering around these species even in the tripositive state, although dielectric saturation effects ${ }^{7}$ may complicate the application of this simple model even to such substitutionally inert complexes. The substitution of ammine by aquo ligands in the series of couples $\mathrm{Ru}$ $\left(\mathrm{NH}_{3}\right)_{6-x}\left(\mathrm{OH}_{2}\right)_{x}{ }^{3+/ 2+}$ is accompanied by sizable increases in $\Delta S^{\circ}$ rc especially for $x=1$ (Table II), indicating that substantial solvent structuring can occur even around an isolated aquo ligand. The experimental values of $\Delta S^{\circ}$ fo for both $\mathrm{Eu}\left(\mathrm{OH}_{2}\right)_{n}{ }^{3+/ 2+}$ (Table I) and $\mathrm{Ru}\left(\mathrm{NH}_{3}\right)_{6}{ }^{3+/ 2+}$ (Table II) depend only slightly upon the total ionic strength, confirming that this quantity is chiefly a consequence of ion-solvent, rather than ion-ion, interactions. The small decreases in $\Delta S_{\mathrm{rC}}^{\circ}$ at ionic strengths approaching unity are probably due in part to ion pairing in the tripositive oxidation state, so that the effective ionic charge of this state is less than +3 .

The substitution of ammine or aquo ligands by simple anions in $\mathrm{Ru}(\mathrm{III}) /(\mathrm{II})$ couples consistently results in substantial decreases in $\Delta S^{\circ}{ }_{\mathrm{rc}}$ (Table II). This effect could arise for at least two reasons. Firstly, the reduction in the net ionic charges is always expected to lower $\Delta S^{\circ}$ ric on the basis of the classical Born model since $\Delta S^{\circ}{ }_{\mathrm{rc}}$ is predicted to depend on the difference of the squares of the ionic charges on the two ions forming the redox couple. Secondly, the replacement of hydrogen-bonding ligands by electronegative ligands should decrease the extent of solvent structuring around these cations. To varying degrees, these two factors are probably responsible for the observed behavior of the chicro and isothiocyanato complexes in Table II. The more dramatic decrease in $\Delta S^{\circ}$ rc for $\mathrm{Ru}\left(\mathrm{NH}_{3}\right)_{5-}$ $\mathrm{OH}^{2+/+}$ compared with $\mathrm{Ru}\left(\mathrm{NH}_{3}\right)_{5} \mathrm{OH}_{2}{ }^{3+/ 2+}$ (Table II) can 
reasonably be attributed to the different hydrogen-bonding characteristics of $\mathrm{OH}^{-}$and $\mathrm{OH}_{2}$. Thus $\mathrm{OH}^{-}$can hydrogen bond to surrounding water molecules via the oxygen atom, which should be favored on electrostatic grounds by coordination to $\mathrm{Ru}(\mathrm{II})$ rather than $\mathrm{Ru}(\mathrm{III})$. In contrast, hydrogen bonding involving aquo ligands will be electrostatically favored by coordination to $\mathrm{Ru}$ (III) rather than $\mathrm{Ru}$ (II) since the hydrogen atoms on the ligands will participate in the bonding.

Although the data for the aquo couples in Table I indicate that some dependence of $\Delta S^{\circ}$ rc upon the electronic structure of the central metal cation is to be expected, part of the variations could arise from differences in the number of aquo ligands that are bound to the central metal ion. Thus $n$ is undoubtedly greater than 6 for $\mathrm{Eu}\left(\mathrm{OH}_{2}\right)_{n}{ }^{3+/ 2+}$ and $\mathrm{Yb}$ $\left(\mathrm{OH}_{2}\right)_{n}^{3+/ 2+}$, which can result in a greater number of hydrogen bonds with the surrounding solvent and may account for the especially large values of $\Delta S^{\circ}$ rc that are observed for these couples. Differences in the polarizing power of the various cations may also be a factor. It is possible that the $\Delta S^{\circ}$ re values for $\mathrm{Ru}$ (III)/(II) couples containing simple unidentate ligands given in Table II provide workable estimates of $\Delta S^{\circ}{ }_{\mathrm{rc}}$ for other couples with the same ligand constitution and charge type. However, it is apparent from the data given in Table III that this assumption may not be reasonable for complexes that contain chelating ligands. Thus the values of $\Delta S^{\circ}{ }_{r c}$ for $\mathrm{Co}(\mathrm{III}) /(\mathrm{II})$ complexes containing ethylenediamine, $o$ phenanthroline, and bipyridine ligands are about $25 \mathrm{eu}$ larger than for corresponding complexes involving other metal cations. These results are both surprising and somewhat puzzling. The behavioral difference between $\mathrm{Ru}(\mathrm{en})_{3}{ }^{3+2+}$ and $\mathrm{Co}$ (en) $3^{3+/ 2+}$ might be explained by differences in ligand conformation that are known for the trivalent complexes 40 giving rise to differences in the surrounding water structure. However, this explanation seems less plausible for the much larger and structurally more open phenanthroline and bipyridine complexes. The values of $\Delta S^{\circ}{ }_{\mathrm{rc}}$ close to zero that were previously found for other phenanthroline and bipyridine couples have been explained by the supposed ability of these aromatic ligands to "shield" the central metal ion from the surrounding solvent. 9.33 The contrasting behavior of the corresponding $\mathrm{Co}(\mathrm{III}) /(\mathrm{II})$ couples clouds this explanation somewhat. Certainly a common feature of these Co(III)/(II) couples is that the change in electronic structure, $\left(\mathrm{t}_{2 \mathrm{~g}}\right)^{6} \rightarrow$ $\left(t_{2 g}\right)^{5}\left(c_{\mathrm{g}}\right)^{2}$, that occurs upon reduction must result in a greater degree of bond stretching and possibly stereochemical change compared with $\mathrm{Fe}(\mathrm{III}) /$ (II) and $\mathrm{Ru}(\mathrm{III}) /(\mathrm{II})$ couples, which involve the conversion $\left(t_{2 g}\right)^{5} \rightarrow\left(t_{2 g}\right)^{6}$. One of the consequences is presumably the release of "bound" water molecules in going from $\mathrm{Co}(\mathrm{III})$ to $\mathrm{Co}$ (II). The relatively small $\Delta S^{\circ}{ }_{\text {rc }}$ (19 eu) found for the Co(sepulchrate) $)^{3+/ 2+}$ couple (Table III) could be a consequence of the "tighter" structure of the macrobicyclic ligand effectively excluding specifically bound water in the higher oxidation state. Additionally, the much smaller $\Delta S^{\circ}$ re values for the $\mathrm{Ru}(\mathrm{III}) /(\mathrm{II})$ and $\mathrm{Fe}(\mathrm{III}) /(\mathrm{II})$ phenanthroline and bipyridine complexes may arise partly from significant delocalization of the added $t_{2 g}$ electron around the aromatic rings. This delocalization can result in additional solvent ordering around these ligands in the divalent state which will counteract the decrease in charge density at the metal center.

The results for mixed ligand complexes presented in Tables II and III suggest that estimation of ionic entropies using empirical correlations based on independent, summable contributions from each ligand ${ }^{2.3}$ can be seriously in error in some cases. Thus the substitution of one ammonia in $\mathrm{Ru}-$ $\left(\mathrm{NH}_{3}\right)_{6}{ }^{3+/ 2+}$ by a water molecule produces almost as large an increase as substitution of the remaining five ammonias to form $\mathrm{Ru}\left(\mathrm{OH}_{2}\right)_{6}{ }^{3+/ 2+}$ (Table II). In contrast, replacement of one bipyridine in $\mathrm{Ru}(\mathrm{bpy})_{3}{ }^{3+/ 2+}$ by two cis water molecules to form cis- $\mathrm{Ru}(\mathrm{bpy})_{2}\left(\mathrm{OH}_{2}\right)_{2}{ }^{3+/ 2+}$ fails to raise $\Delta S^{\circ}{ }_{\mathrm{rc}}$ significantly above zero (Table III). The effect of aquo ligand substitution can therefore depend upon the nature of the surrounding ligands and indicates that the mutual environment of individual ligands can be an important factor in determining their influence upon $\Delta S^{\circ}$ rc.

Aside from yielding information on the thermodynamics of ion solvation, such values of reaction entropies for redox couples listed in Tables I-III may also provide otherwise elusive clues as to some factors that influence outer-sphere redox reactivity. In particular, it is interesting to note that the $\Delta S^{\circ}$ rc values for the aquo couples that are listed in Table I vary roughly inversely with their homogeneous self-exchange rates which apparently refer to outer-sphere pathways. ${ }^{41 a}$ Although the extremely small rate constant $k_{\text {ex }}$ for $\mathrm{Cr}\left(\mathrm{OH}_{2}\right)_{6}{ }^{3+/ 2+}$ self-exchange must be due in part to the large changes in ligand-metal bond distances that are required in order to transfer an e electron, ${ }^{41}$ the very slow rate of $\mathrm{Eu}\left(\mathrm{OH}_{2}\right)_{n}{ }^{3+/ 2+}$ self-exchange $\left(k_{\mathrm{ex}} \sim 1 \times 10^{-5} \mathrm{M}^{-1} \mathrm{~s}^{-1}\right)$ and also for $\mathrm{Yb}\left(\mathrm{OH}_{2}\right)_{n}{ }^{3+/ 2+42}$ are surprising since the transfer of an $\mathrm{f}$ electron is not expected to result in a large inner-sphere (i.e., metal-ligand bond stretching) contribution to the FranckCondon barrier. ${ }^{41}$ : On the other hand, the transfer of a similarly nonbonding $\mathrm{t}_{2 \mathrm{~g}}$ electron for $\mathrm{Ru}\left(\mathrm{OH}_{2}\right)_{6}{ }^{3+/ 2+}$ self-exchange occurs much more rapidly $\left(k_{\mathrm{ex}}=60 \mathrm{M}^{-1} \mathrm{~s}^{-1}, \mu=1^{47}\right)$ but significantly more slowly than $\mathrm{Ru}\left(\mathrm{NH}_{3}\right)_{6}{ }^{3+/ 2+}$ self-exchange $\left(k_{\mathrm{ex}} \sim 8 \times 10^{2} \mathrm{M}^{-1} \mathrm{~s}^{-1}, \mu=0.013^{48}\right)$. The conventional, dielectric continuum treatment of outer-sphere (solvent) reorganization ${ }^{(45,49)}$ predicts that this contribution to the Franck-Condon barrier should be approximately the same for all these systems. ${ }^{41 a}$ The variations in the $\Delta S^{\circ}{ }_{r c}$ values for these systems that are seen in Tables I and II suggest that an important reason for these large differences in redox reactivity may be the extent to which hydrogen bonds between the coordinated ligands and the surrounding solvent are required to be made or broken in order for electron transfer to occur. Such a contribution to the Franck-Condon barrier is not considered in the simple dielectric continuum model and can in principle account for the small self-exchange rates for aquo couples. The $\Delta S^{\circ}$ rc values indicate that the contribution will be largest for $\mathrm{Eu}\left(\mathrm{OH}_{2}\right)_{n}{ }^{3+/ 2+}$ and other aquo exchanges and smallest for $\mathrm{Ru}\left(\mathrm{OH}_{2}\right)_{6}{ }^{3+12+}$ and $\mathrm{Ru}\left(\mathrm{NH}_{3}\right)_{6}{ }^{3+/ 2+}$ exchange, which is in harmony with the differences in their self-exchange rates. Of course, this effect could not directly stem from differences in entropic driving forces because these must be equal to zero for self-exchange reactions. Rather, these thermodynamic entropy differences are regarded as a signal indicating that additional solvent reorganization may be required in order for electron transfer to occur, which will increase the intrinsic part of the reorganization energy. ${ }^{45,49}$

This crude connection between the magnitude of the rate constants for outer-sphere self-exchange and $\Delta S^{\circ}{ }_{r c}$ also appears to hold for a number of other couples in Tables II and III Thus the $\mathrm{Co}(\mathrm{en})_{3} 3^{3+12+}, \mathrm{Co}(\text { phen })_{3} 3^{3+2+}$, and $\mathrm{Co}-$ (bpy) $3^{3+/ 2+}$ couples that exhibit values of $\Delta S^{\circ}$ rc that are

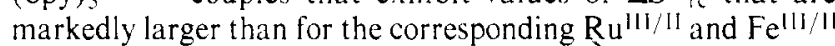
systems (Table III) also exhibit rate constants for self-exchange that are surprisingly small in comparison with the rate constants for these latter systems. It is possible that part of this large additional barrier to electron transfer for $\mathrm{Co}($ III $) /($ II) self-exchange arises from structural changes in the surrounding solvent, as well as from the especially large inner-sphere contributions expected for these systems. ${ }^{41}$

\section{Conclusions}

Although this survey is far from comprehensive, it is felt that the results presented above allow some general conclusions to be reached which may well have wide validity.

(1) For simple aquo redox couples $\mathrm{M}\left(\mathrm{OH}_{2}\right)_{n}{ }^{3+/ 2+}$, the 
nature of the central metal ion appears to have only a relatively small effect upon $\Delta S^{\circ}{ }_{\mathrm{rc}}$. The observed variations in $\Delta S^{\circ}{ }_{\mathrm{rc}}$ (36-49 eu) probably result primarily from differences in the extent of solvent "structure making" in the higher oxidation state.

(2) Ammine couples exhibit markedly smaller $\Delta S^{\circ}$ rc values compared with the corresponding aquo couples, presumably owing to the lower tendency of ammine protons to engage in hydrogen bonding with the surrounding solvent.

(3) The substitution of aquo or ammine by anionic ligands also results in substantial decreases in $\Delta S^{\circ}{ }_{\mathrm{rc}}$.

(4) At least for redox couples containing chelating ligands, the values of $\Delta S^{\circ}$ rc can depend upon the electronic structure of the oxidized and reduced metal cations as well as their charge and the nature of the surrounding ligands.

Although a large fraction of the systems studied with unidentate ligands involve $\mathrm{Ru}(\mathrm{III}) /(\mathrm{II})$ couples, it is anticipated that the $\Delta S^{\circ}$ rc values predominantly reflect ligand rather than metal characteristics so that such data could be used to estimate entropic driving forces for redox reactions for which these terms are not measurable. Unfortunately, it appears that very few other metal couples would provide tractable systems, even using rapid electrochemical pulse techniques, so that this assertion may remain inadequately tested. Nevertheless, it is hoped that such data, coupled with accurately determined activation parameters for the kinetics of electron transfer, $4 \mathrm{lb}$ may yet help to unravel some of the still poorly understood physical factors that influence redox reactivity in homogeneous solution and at electrode surfaces.

Acknowledgments. Scott Nettles and Leonore Rubin willingly performed some additional experiments. Dr. Gilbert Brown and Professor John Endicott supplied a number of the compounds used in this study and also provided valuable sources of advice and encouragement. Professor Frank Bottomley also supplied useful advice on osmium ammine syntheses. One of the authors (P.D.T.) wishes to express appreciation of a fellowship from the General Electric Corp. through a grant to the Department of Chemistry at Michigan State University. The support of this work by the Air Force Office of Scientific Research is gratefully acknowledged.

\section{References and Notes}

(1) R. E. Powell and W. M. Latimer, J. Chem. Phys., 19, 1139 (1951)

(2) J. W. Cobble, J. Chem. Phys., 21, 1446 (1953).

(3) P. George, G. I. H. Hanania, and D. H. Irvine, J. Chem. Phys., 22, 1616 (1954); Recl. Trav. Chim. Pays-Bas, 75, 759 (1956).

(4) H. S. Frank and M. W. Evans, J. Chem. Phys., 13, 507 (1945); H. S. Frank and W.-Y. Wen, Discuss. Faraday Soc., 24, 133 (1957).

(5) R. E. Powell, J. Phys. Chem., 58, $528(1954)$

(6) K. J. Laidler, Can. J. Chem., 34, 1107 (1956)

(7) R. M. Noyes, J. Am. Chem. Soc., 84, 513 (1962).

(8) M. J. Weaver, J. Phys. Chem., 80, 2645 (1976)

(9) J. Lin and W. G. Breck, Can. J. Chem., 43, 766 (1965).

(10) H. S. Lim, D. J. Barclay, and F. B. Anson, Inorg. Chem., 11, 1460 (1972).

(11) G. N. Coleman, J. W. Gesler, F. A. Shirley, and J. R. Kuempel, Inorg. Chem., $12,1036(1973)$.
(12) C. M. Elson, I. J. Itzkovitch, J. Mckenney, and J. A. Page, Can. J. Chem., 53, $2922(1975)$.

(13) T. Matsubara and P. C. Ford, inorg. Chem, 15, 1107 (1976)

(14) J. A. Marchant, T. Matsubara, and P. C. Ford, Inorg. Chem., 16, 2160 (1977).

(15) J. Gulens and J. A. Page, J. Electroanal. Chem., 55, $239(1974) ; 67,215$ (1976).

(16) M. J. Weaver, submitted for publication.

(17) B. E. Conway and J. O'M. Bockris in "Modern Aspects of Electrochemistry" Vol. I, J. O'M. Bockris and B. E. Conway, Eds., Butterworths, London, 1954, Chapter 2.

(18) R. Gomer and G. Tryson, J. Chem. Phys., 66, 4413 (1977).

(19) C. M. Criss and M. Salomon in 'Physical Chemistry of Organic Solvent Systems", A. K. Covington, and T. Dickinson, Eds., Plenum Press, New York, 1973, Chapter 2

(20) For a general review, see J. N. Agar, Adv. Electrochem. Electrochem. Eng., 3, 31 (1963).

(21) For example, see (a) E. D. Eastman, J. Am. Chem. Soc., 50, 292 (1928); (b) A. J. deBethune, T. S. Licht, and N. Swendeman, J. Electrochem, Soc., 106, 616 (1959); A. J, deBethune, ibid., 197, 829 (1960); (c) G. Milazzo and M. Sotto, Z. Phys. Chem. (Frankfurt am Main), 52, 293 (1967); G. Milazzo, M. Sotto, and C. Devillez, ibid., 54, 1 (1967).

(22) Values were obtained from relative Thomson coefficients (vs. Pb) quoted in G. P. Harnwell, "Principles of Electricity and Magnetism", McGraw-Hill, New York, 1939, p 187, combined with the absolute Thomson coefficient for $\mathrm{Pb}$ given in ref 20

(23) G. I. H. Hanania, D. H. Irvine, W. A. Eaton, and P. George, J. Phys. Chem., 71, 2022 (1967).

(24) (a) R. S. Nicholson and I. Shain, Anal. Chem., 36, 706 (1964); (b) R. S. Nicholson, ibid., 37, $1351(1965)$.

(25) L. H. Vogt, Jr., J. L. Katz, and S. E. Wiberley, Inorg. Chem., 4, 1157 (1965).

(26) K. Gleu and W. Breuel, Z. Anorg. Allg. Chem., 237, 197 (1938).

(37) F. Bottomley and S.-B. Tong, inorg. Chem., 13, 243 (1974).

(28) J. B. Work, Inorg. Synth., 2, 221 (1953)

(29) Quoted in ref 1

(30) R. R. Buckley and E. E. Mercer, J. Phys. Chem., 70, 3103 (1966)

(31) D. K. Lavallee, C. Lavallee, J. C. Sullivan, and E. Deutsch, Inorg. Chem. 12, 570 (1973); C. Lavallee and D. K. Lavallee, ibid., 16, 2601 (1977).

(32) J. J. Kim and P. A. Rock, Inorg. Chem., 8, 563 (1969).

(33) P. George, G. I. H. Hanania, and D. H. Irvine, J. Chem. Soc., 3548 (1959).

(34) I. I. Creaser, J. MacB. Harrowfield, A. J. Herlt, A. M. Sargeson, J. Springborg, R. J. Gene, and M. R. Snow, J. Am. Chem. Soc., 99, 3181 (1977).

(35) (a) M. P. Liteplo and J. F. Endicott, J. Am. Chem. Soc., 91, 3982 (1969); Inorg. Chem., 10, 1420 (1971); (b) D. P. Rillema and J. F. Endicott, J. Am Chem. Soc., 94, 8711 (1972); Inorg. Chem. 11, 2361(1972).

(36) "Handbook of Chemistry and Physics", 56th ed., CRC Press, Cleveland, Ohio, 1975-1976, p F-209

(37) For example, see F. Basolo and R. G. Pearson, "Mechanisms of inorganic Reactions", 2nd ed., Wiley, New York, 1967, pp 62-64.

(38) E. R. Nightingale, J. Phys. Chem., 63, 1381 (1959); T. Takahashi and T. Koiso, Bull. Chem. Soc. Jpn., 49, 2784 (1976).

(39) M. J. Weaver and T. L. Satterberg, J. Phys. Chem, 81, 1772 (1977).

(40) H. J. Peresie and J. A. Stanko, Chem. Commun., 1674 (1970).

(41) See, for example, (a) R. G. Linck in "Homogeneous Catalysis", G. N. Schrauzer, Ed., Marcel Dekker, New York, 1971, Chapter 7; (b) L. E. Bennett, Prog. Inorg. Chem., 18, 1 (1973); (c) N. Sutin in "Inorganic Biochemistry", Vol. 2, G. L. Eickhorn, Ed., American Elsevier, New York, 1973, Chapter 19

(42) $K_{\text {ex }}$ for $\mathrm{Eu}^{3+i 2+}$ self-exchange has been estimated to be $1 \times 10^{-5} \mathrm{M}^{-1} \mathrm{~s}^{-1}$ $(\mu=1)$ from cross-reaction data. ${ }^{43}$ A comparable value $\left(\sim 1 \times 10^{-4} \mathrm{M}^{-1}\right.$ $\left.\mathrm{s}^{-1}\right)$ can be obtained from the electrochemical standard rate constant $k_{\mathrm{e}}$ $\left(5 \times 10^{-4} \mathrm{~cm} \mathrm{~s}^{-1}, \mu=1^{44}\right)$ using the Marcus relation. ${ }^{45}$ No reliable estimates of $k_{\text {ex }}$ for $\mathrm{Yb}^{3+12+}$ are available, but $k_{\text {el }}$ values for $\mathrm{Eu}^{3+12+}$ and $\mathrm{Yb}^{3+12+}$ are comparabie after correcting for double layer work terms. ${ }^{46}$

(43) A. Adin and A. G. Sykes, J. Chem. Soc. A, 1230 (1966); M. Chou, C. Creutz, and N. Sutin, J. Am. Chem. SoC. 99, 5615 (1977)

(44) M. J. Weaver and F. C. Anson, J. Electroanal. Chem. 65, 711(1975).

(45) R. A. Marcus, J. Phys. Chem., 67, 853 (1963).

(46) Z. Borkowska and H. Elzanowska, J. Electroanal. Chem., 76, 287 (1977).

(47) Calculated using the Marcus "cross-relation" 45 from cross-reaction rates involving $\mathrm{Ru}\left(\mathrm{OH}_{2}\right)_{6}{ }^{3+}$ (W. Bottcher, G. M. Brown, and N. Sutin, submitted for publication)

(48) T. J. Meyer and H. Taube, Inorg. Chem, 7, 2369 (1968).

(49) R. A. Marcus, J. Chem. Phys., 43, 679 (1965). 